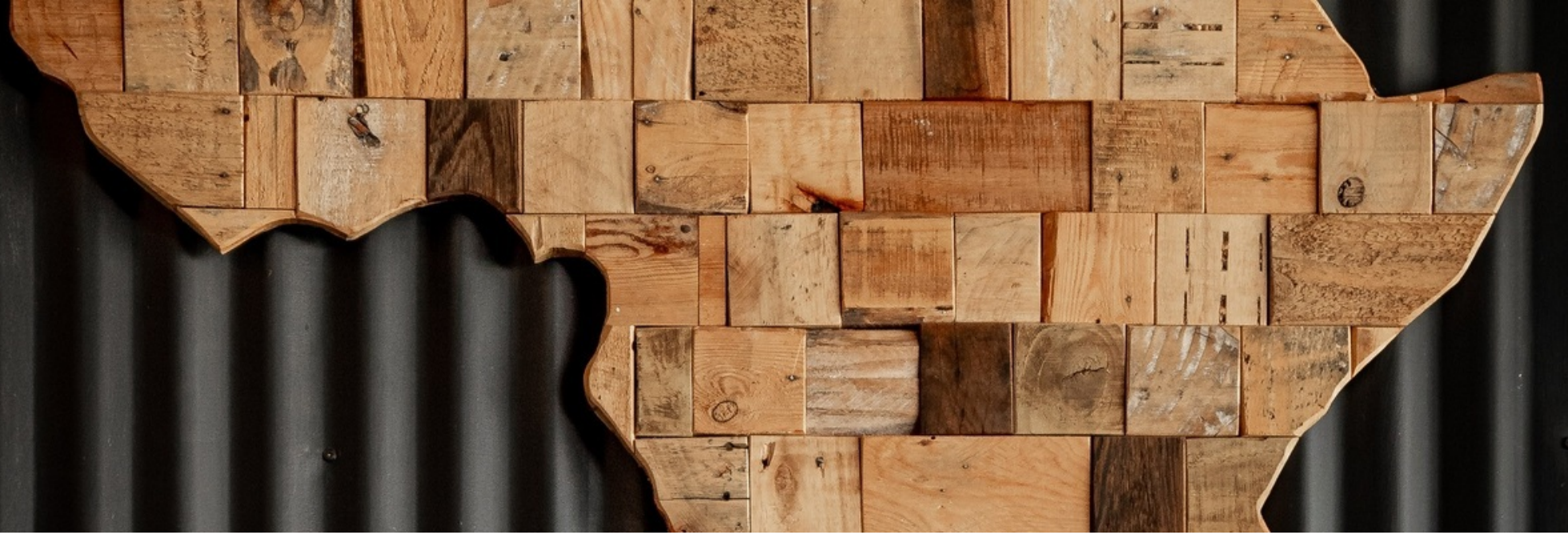

\title{
Clitoridectomy among Shuwa Arabs of Borno, Nigeria
}

\section{Authors: Usman Al-amin}

Submitted: $\quad$ 23. October 2021

Published: $\quad$ 25. October 2021

Volume: 8

Issue: $\quad 4$

Affiliation: Department of History. University of Maiduguri. Borno State, Nigeria

Languages: English

Keywords: $\quad$ Clitoridectomy, genitalia, circumcision, mutilation, Shuwa Arabs, female

\section{Categories: Humanities, Social Sciences and Law}

DOI: $\quad$ 10.17160/josha.8.4.785

\section{Abstract:}

The study focuses on the origin, nature and effects of Clitoridectomy among Shuwa Arabs of Borno, Nigeria. Clitoridectomy comprises of various procedures which removes or damage the external female genital organs for no medical reasons or purpose. It has no health benefits and is recognized to cause severe short- and long-term damage to both physical and psychological health of the victims. The study reveals that despite the negative health consequences, yet the Shuwa Arabs still adhere to the practice and consider it as normal as the circumcision are normal in almost every other community.

\section{JOSHA Jumna ossemene. Humanities and Arts}




\title{
Clitoridectomy among Shuwa Arabs of Borno, Nigeria
}

\author{
Usman Al-amin, alaminusman81@gmail.com \\ and
}

Abdulsalam Abba Tor, atorsalam21@gmail.com

Department of History, University of Maiduguri, Borno State, Nigeria

Key words: Clitoridectomy, genitalia, circumcision, mutilation, Shuwa Arabs, female.

\section{Abstract}

The study focuses on the origin, nature and effects of Clitoridectomy among Shuwa Arabs of Borno, Nigeria. Clitoridectomy comprises of various procedures which removes or damage the external female genital organs for no medical reasons or purpose. It has no health benefits and is recognized to cause severe short- and long-term damage to both physical and psychological health of the victims. The study reveals that despite the negative health consequences, yet the Shuwa Arabs still adhere to the practice and consider it as normal as the circumcision are normal in almost every other community. 


\section{Introduction}

Clitoridectomy which is also referred as female genital mutilation (FGM), female cutting or female circumcision, is the ritual cutting or removal of some or all the external female genitalia. ${ }^{1}$ Put simply, clitoridectomy include the removal of the clitoral hood and clitoral glans. Removal of the inner labia; and removal of the inner and outer labia and closure of the vulva. In the last procedures, which is also known as infibulation, a small hole is left for the passage of urine and menstrual fluid; the vagina is opened for intercourse and opened further for childbirth. ${ }^{2}$ The practice is found in Egypt, Sudan, Djibouti, Mauritania, Yemen, Somalia, Iraq to mention a few. ${ }^{3}$ In Borno, among the Shuwa Arabs, the practice is include the procedures to alter or cause injury to the female genital organs for religious and cultural reasons, which has no health benefits for the circumcised person. ${ }^{4}$ The practice among the Shuwa Arabs is rooted in gender inequality, attempt to control female or woman' sexuality and ideas about purity, modesty and beauty. They also see it as source of honour and who fear that failing to have their daughters and granddaughters cut or circumcise will expose the girls to social exclusion. ${ }^{5}$ The practice is mostly carried out by traditional circumcisers, more especially old women who often play other central or ceremonial roles in the communities, such as the after during childbirths. Equally in some communities, health care providers perform the cutting do to the erroneous belief that the procedure is safer when medicalized. ${ }^{6}$

\section{The Shuwa Arabs in Borno}

Borno State was created on 13th February 1976, from the defunct North-eastern State. It was located within latitude $10 \mathrm{~N}$ and $14 \mathrm{~N}$ and longitude $1130 \mathrm{E}$ and $1445 \mathrm{E}$ and it has an area

\footnotetext{
${ }^{1}$ Lightfoot-Klein 1991, 3.

${ }^{2}$ WHO 2006. Accessible at view Article Google Scholar.

${ }^{3} \mathrm{DW}$ article available at https://www.dw.com/en/where-does-the-arab-world-stand-on-female-genital-mutilation/a42472991 retrieved on 16.10.2020.

${ }^{4}$ Interview with Abba Kala and Hajja Khaltum in Maiduguri on $11^{\text {th }}$ September, 2017.

${ }^{5}$ Ibid, interview with Abba Kala.

${ }^{6}$ Female Genital mutilation/cutting: A global concern, UNICEF, New York, 2016.
} 


\section{JOSHA}

Journal of Science, Humanities and Arts

of $61,435 \mathrm{sq} . \mathrm{km}$ being the largest state in the Nigeria in terms of land mass. Located in the North Eastern corner of Nigeria, the State occupies the greatest part of the Chad Basin and shares borders with the Republics of Niger to the North, Chad to the North-East and Cameron to the East. It is the only State in the entire Federation sharing border with three countries. The 1999 population census indicates that Borno State has the estimated population of six hundred and twenty nine thousand four hundred and eighty six $(629,486)$ people. Based on the five percent annual increment the population of Borno in 1999 said to be $(885,750) .{ }^{7}$ The major tribes are Kanuri, Margi, Babur, Hausa, Shuwa Arabs. It is generally believed that the present day Shuwa Arabs of Borno are descendants of Arab immigrants who found their way into Kanem in the late fourteenth century. ${ }^{8}$ Since that period, it has been suggested, they came to be locally called Shuwa Arabs in Borno and they are estimated to be nearly 303,000. ${ }^{9}$ The Shuwa Arab are Sunni Muslims, and most participate in the Tijānīyya Sufi brotherhood.

\section{Brief History of clitoridectomy}

Although many consider female circumcision with Islamic connection or orientation among Muslims, but historical record prove otherwise. Records show that the practice predates Islam, and it is not perform in most Muslim countries. ${ }^{10}$ Same revealed that there are sign of clitoral excision since $6^{\text {th }}$ century B.C, and the practice of clitoridectomy is also known in the western countries. During this period, this practice is typically carried out by a traditional circumciser, using a blade, which mostly are unsterilized and is conducted from days after birth to puberty and at times beyond. Also, sources further indicates that most of the girls cut before the age of five to ten, but the method of cutting is different according to cultural tradition and procedure of the cutting. ${ }^{11}$ The practice performed into the 1940 's to treat masturbation,

\footnotetext{
${ }^{7} 1999$ Population census.

${ }^{8}$ Modu 2015, 26 citing Fadl-Hassan 1992,1.

${ }^{9}$ Online archived from https://archive.li/20171120071725/https://joshuaproject.net/people groups/14926 retrieved on 16.10.2020.

${ }^{10}$ Op. cit. Lightfoot-Klein, "Prisoners of Ritual."

${ }^{11}$ Hodakinson and Hiat1983, 74-114.
} 
insanity, epilepsy, and hysteria. ${ }^{12}$ Equally early western countries physicians have also incised the clitoral prepuce to treat frigidity and perform aesthetic vaginal labioplastics to reduce the size of the clitoris and labia. ${ }^{13}$ Today, it is practiced by Muslims, Christians and Animist alike. Thus it has long been concluded to be a cultural practice that has little connection to religion ${ }^{14}$.

\section{Clitoridectomy Among Shuwa Arabs}

The practice of clitoridectomy among the shuwa people is as old as the history of the people itself. In other words, the people practice it since time out of mind, and one cannot remember when and how the practice came into play, through greater majority of the practitioners associated it to the time of Prophet Mohammad that is nearly 1500 years ago. ${ }^{15}$ Today in Borno, majority of Shuwa girls had genital alteration that involved the cutting and removal of portion of the external female genitalia, without stitching and the procedures had been practice or done in early childhood, usually before the age 10 , by a traditional circumcisers. ${ }^{16}$ Among the Shuwa people, circumcised girls or when genitalia are consider normal, just as circumcised male genitalia are normal in almost every other communities. ${ }^{17}$ In most cases of clitroridectomy among this people, usually a girl's clitoris and labia are cut away completely, often with crude unsterile instruments, without anesthetics by a traditional practioners. Circumciser, who has little or no knowledge with regards female anatomy. ${ }^{18}$

Not until recently, the people regarded the practice of clitoridectomy as a necessary condition of life, thus believing it as customs or traditional. The above notwithstanding, other groups who perform the practice often offer a mix cultural and religious reasons for the cutting of young girls. They mostly belief that cutting of girls prevents them from social vices and makes

\footnotetext{
12 Sheehan 1982, 12-15.

${ }^{13}$ Ibid.13; see also Peter Lewis Allan 2000, 106.

${ }^{14}$ Ibid. 74-114.

${ }^{15}$ Interview with Hajja Asheh Hassanari, in Maiduguri on $20^{\text {th }}$ April, 2018.

${ }^{16}$ Ibid.

${ }^{17}$ Ibid. However, the issues female genital mutilation among Shuwa stock is common and popular among most Bornoan, and this is so because the group adhered to the practice which they inherited from their ancestors.

${ }^{18}$ Op. Cit. HodaKinsson, "Aeasthetic vaginal labioplasty". Also check https://www.mtholyoke.e.
} 
them more attractive for future husbands. Also some mother's fear that their daughters cannot get husband or be married if they have not been circumcise or cut. ${ }^{19}$ Also, since the Shuwa people are Muslims, insisting that it is a "Sunnah" of the prophet in other words, it was simply done that the times of the prophet, though some scholars maintained that, the practice is not prohibited, nor obligatory in Islam.

In the Islamic or Sunnahtic cutting girls clitoris is shaved or cut off completely. ${ }^{20}$ Other known methods practice include the removal of the clitoris and labia, with the vagina from both sides and stiches together with thread, thus leaving only a small opening via which the girls can urinate and which menstrual blood can come through. ${ }^{21}$ The Shuwa people believed that the practice have some important to the circumcise girls, and these interalia are;

i. It can ensure virginity (maintain chastity before marriage);

ii. It can ensure fidelity during marriage.

iii. It can secure or enhance fertility.

iv. It will create male sexual pleasure;

v. It will prevent the clitoris from growing long;

vi. It will keep the girl clean and hygienic;

vii. And also by reducing or eliminating of the female genitalia, it is belief that it will attenuate the sexual desire in the female $\mathrm{e}^{22}$.

\section{Health and other Effects Associated with Clitoridectomy}

Clitoridectomy is recognized internationally as the violation of the human rights of the girls and women that were circumcise and constitute an extreme form of discrimination against women due to the severe health consequences and the pain and risks involved in the procedure. Also since the procedures is carried out by a traditional circumcisers, who use the same blade

\footnotetext{
${ }^{19}$ Op. cit., interview with Hajja Asheh Hassanari.

${ }^{20}$ Ibid.

${ }^{21}$ History of female Genital Mutilation (FGM), accessible at http://www.disability. Retrieved on 16.10.2020.

${ }^{22}$ Ibid.
} 
albeit and which is mostly not sterilize the procedure might lead to recurrent infections, difficult urination and passing of menstrual flow, chronic pain, the development of cysts an inability to get pregnancy at times complication during childbirth and fatal bleeding during and after, the cutting or circumcision. Equally important health experts conclude or belief that there is no single known health benefits associated with clitoridectomy. ${ }^{23}$

It is petinent to know that among the various Shuwa groups, which includes both the nomadic and semi-nomadic and to some extent the settled one's there was no mush differences between the men and women who knew the health consequences and risk associated with the practice they so cherish. ${ }^{24}$

\section{Conclusion}

Despite the long history of the practice among the various Shuwa clans and groups, and the significances attached to it, in terms of religions and culture rites, that the practice is reduce in almost all the communities that practice it hither to, through some few people still adhere to the custom and practice it than to the social acceptance, cultural religious hygiene, preservation of virginity, marriageability and the enhancement of sexual pleasure. Also, because of the poor access to vital information with regards circumcision and equally because circumcisers downplay the causal connection, women may not associate the health consequences with the practice. Thus, to reduce or eliminate completely the practice of clitoridectomy there is the need to generate knowledge about health risk and consequences of the practice, including how to eliminate it and on how to care for those who have experienced it. Added to these, there is the need for increasing the development of publication and advocacy tools for international regional national and local efforts to end the menace. There is the also to revise some of the legal frame work and growing political support to eliminate and end the matter totally. Finally, an emphasis

\footnotetext{
${ }^{23}$ Global Health Research: effects of female Genital cutting on physical health outcomes; a systematic review and meta-analysis accessible at http; // Creative commons.org/licenses/by-nc/4.D.

${ }^{24}$ Op. cit., interview with Abba Kaka and Hajja Khaltum.
} 
be put on the further engagement of traditional leaders or native authorities, which has the power to make binding cultural decision for their various communities and a subsequent educational campaign aimed at imparting knowledge, changing attitudes and ultimately behavioral change should be encourage at all cost. 


\section{References}

Adam, Biraima M. (2012), Baggara of Sudan: Culture and Environment, Amazon online Books accessible at Baggara of Sudan: Culture and Environment retrieved on 16.10.2020.

DW article available at https://www.dw.com/en/where-does-the-arab-world-stand-on-femalegenital-mutilation/a-42472991 retrieved on 16.10.2020.

Female Genital mutilation/cutting: A global concern, UNICEF, New York, 2016.

Global Health Research: effects of female Genital cutting on physical health outcomes; a systematic review and meta-analysis accessible at http; // Creative commons.org/licenses/by-nc/4.D.

Hanny lightfoot-Klein(1991), "Prisoner of Ritual; some contemporary Development in the History of female genital mutilation" presented at the second international symposium on circumcision in San Francisco, April 30-May.

History of female Genital Mutilation (FGM), an internet Source accessible at http://www.disability world. Ora /01-03-04/ women/Fgm.shtml. Also check https://www.mtholyoke.e

Hodakinson D, Hiat G. (ed) (1983), Aesthetic vaginal labiaplasty. Past Reconstruction. Sung: Pubmed.

Modu, Ibrahim Alhaji (2005), "Migration as a Response to the Environmental Push and Pull Factors: A Case of the Study of the Shuwa Arab Migration into Borno, in Al-Mahram vol. 2, No.1.

Peter Lewis Allan, (2000), "The wages of Sin": Sex and Disease, Past and present. Chicago: University of Chicago Press.

Sheehan E. (1982), "Victorian clitoridectomy" in Med-Anthropol News. 
WHO study group on female Genital Mutilation and obstetric outcome: WHO collaborative prospective study in Six African Countries, lancet, 2006. Accessible at view Article Google Scholar.

\section{List of the respondents}

Abba Kala and Hajja Khaltum

Hajja Asheh Hassanari

\section{About the authors}

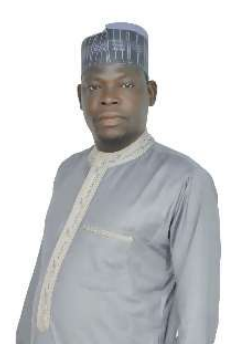

Usman Al-amin is a lecturer in the Department of History, University of Maiduguri, Nigeria. His main fields of research include Sufism and manuscripts cultures in the context of African intellectual history, in particular, the formative period up to the 20th century, and the historiography of Islamic sects in modern and contemporary Nigeria. He recently developed interest in the cultural history of Kanuri. He has published extensively in journals, contributed dozens of chapters to books, and presented so many academic papers in local and international conferences. In addition, he has been invited to research, write papers, and make presentations for several government functions and civil society fora. His recent researches include: Nguru Islamic Scholars in Perspective: The Contributions of Sheikh 'Uthmān al-Fallātī alGhūrāwī al-Barnāwī at-Tijānī (1909 CE/1330 AH) to Islamic Education Attires for the Royalty among the Kanuri Speaking People; Elements of Continuity and Change in the Marriage Customs of the Kanuri Speaking People in Maiduguri Metropolis of Borno State, 1990- 2012; The Unknown Colonial Scars on Nigeria: The Impact of the Second World War on Nguru District (Borno Province), 1939-1945; The Growth of Pharmaceutical Business in Borno State, Nigeria, 1976- 
1999; The Role of Community-Based Agricultural and Rural Development Programme in Poverty Reduction in Bursari Local Government Area of Yobe State, Nigeria: 2005-2009, to mention a few.

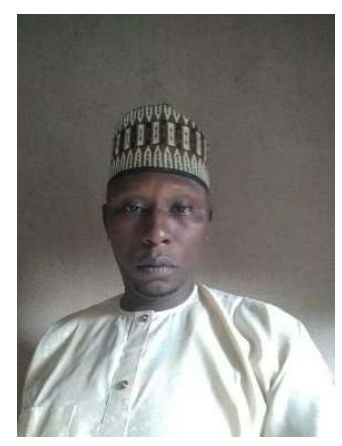

Abdulsalam Abba Tor is also a lecturer in the Department of History, University of Maiduguri, Nigeria. He specializes in International History and Diplomacy. His scholarly publications have national and international outlets. His recent publication is Nallê Arts: Notes on Some Aspects of Henna Application among the Kanuri People of Borno, Nigeria 